\title{
Charcot-Marie-Tooth disease type 4G
}

INSERM

\section{Source}

INSERM. (1999). Orphanet: an online rare disease and orphan drug data base. CharcotMarie-Tooth disease type 4G. ORPHA:99953

Charcot-Marie-T ooth disease type 4G (CMT 4G) is a subtype of Charcot-Marie-Tooth disease type 4 characterized by early childhood onset of progressive distal muscle weakness and atrophy, delayed motor development, prominent distal sensory impairment, areflexia, moderately reduced nerve conduction velocities, and foot and hand deformities in Balkan (Russe) Gypsies. 